of the year are made light of, and the difficulties which the arid climate offers to the detailed examination of an extensive tract of such country have to be experienced in order that they may be fully appreciated

H. G. L.

\section{THE LAWES AND GILBERT CENTENARY FUND.}

IUST a hundred years ago was born John $\int$ Bennett Lawes, followed three years later by his life-long collaborator, John Henry Gilbert; together they carried on their scientific work until the end of the nineteenth century, and now preparations are being made to commemorate the year of Lawes' birth by rebuilding the laboratory in which so much of the pioneer work in agricultural science was done. The issue of the Annual Report on the Rothamsted Experiments reminds us of the historic claims of that institution to all the assistance the public can give it.

Lawes began his agricultural experiments so far back as 1838 , but though those early essays led to the invention of superphosphate and so incidentally to the fortune from which he so liberally endowed the Rothamsted Station, the experiments, properly speaking, did not begin until I842, when Gilbert became associated with them. From that time some of the famous fields began to take shape, and by 1852 had settled down to that scheme of manuring which has never since been changed; in consequence, the plots now supply data as to the effect of fertilisers both upon. the crop and upon the soil which are not merely unrivalled in their trustworthiness, but are constantly being re-interpreted as the science of the nutrition of the plant develops. In 1855 the laboratory was built from subscriptions raised as a testimonial to the value of Lawes' work, and it is this laboratory, now out of date and becoming structurally unsound, that the Rothamsted Committee seeks to replace.

Lawes died in 1900 , Gilbert in rgor, and that first long and honourable chapter in the history of Rothamsted was closed. With the appointment of a new Director, Mr. A. D. Hall, in Igoz, came the desire for a fresh outlook upon the old experiments; new points of view had arisen, particularly the physical and biological aspects of the soil had become important. The first necessity was to get together a body of workers, for one man could no longer cover so complex a field, and to find adequate accommodation for them, because the arrangements of the old laboratory, though equal to the routine determinations which Gilbert needed, were extremely primitive. Unfortunately, the endowment of the Lawes' Trust provided no margin for extension; still the laboratory was reformed, a few voluntary assistants were secured and new ground broken. After a time Mr. J. F. Mason built a new wing for bacteriology and enabled Dr. H. B. Hutchinson to join the staff, and a little later the Goldsmiths' Company added to the endowment so that the services of Dr. E. J. Russell cnild he secured.
Up to that time no assistance came from Government, but with the creation of the Development Fund in I9ro, the Rothamsted Station became recognised as the Institute for the investigation of the soil and the nutrition of the plant, and received an adequate endowment. The first result was that the Committee was able not only to add some experienced workers to the staff, but also to take a long lease of the home farm containing the classic fields and to embark upon the erection of an additional laboratory with all modern conveniences of electric supply, vacuum and air current, etc. At that point Mr. Hall resigned the Directorship, and was succeeded by Dr. Russell, who has no sooner got the new laboratory opened than he has set about the replacement of the old one which, even were it adaptable to modern methods of work, has for years been giving trouble owing to original detects in construction.

Subscriptions have been received from all parts of the world, the farming societies, large and small, in Great Britain, have contributed in a way that shows their increased appreciation of research, but nearly roool. are still wanted to complete the $6000 l$. that it is necessary to raise from the public. The laboratory is expected to cost I2,oool., towards which there is reason to expect the Development Commissioners will give a sum equal to that raised from other sources, so now is the time for everyone interested in the welfare of this doyen of institutions for agricultural research to send along their donations from which the Rothamsted Station will reap a double benefit.

\section{THE LIFE-HISTORY OF THE EEL. ${ }^{1}$}

M ANY articles in Nature have dealt, during 1 recent years, with the above subject; but its interest is not exhausted, and we here welcome the appearance of three new contributions to the long-debated question of the eel.

Dr. Grassi's work is the first publication of the Italian Royal Commission on "Thalassography," and in these first-fruits the commission gives promise of a great return from its systematic exploration of the Mediterranean Sea. Mr. Lea's paper is one of the many beautiful and interesting monographs which have already been based on the collections made by Sir John Murray and Dr. Hjort in the deep waters of the Atlantic. Dr. Bowman's paper is a brief but interesting note, based on the work of the Scottish research vessel Goldseeker.

In a long and learned introduction Dr. Grassi relates the history of our knowledge of the lifehistory of the eel; and while this history has been often summarised, it is here told more completely than ever. Dr. Grassi goes back even to Aristotle,

\footnotetext{
1 "Metamorphose der Murænoiden: Systematische und Oekologische Untersuchungen "(Text Italienisch). By Dr. Battista Grassi. Pp. X+2I + "xv plates. (Jena: Gustav Fischer, 1913.) Price 50 marks.

"Murænoid Larvæ from the Michael Sars North Atlantic Expedition, 19ro." By Einar Lea. In vol. iii. of the Scientific Reports of the Expedition. Pp. $59+6$ plates. (Bergen : John Grieg, I913.)

"The Distribution of the Larvæ of the Eel in Scottish Waters." By Alexander Bow man, D.Sc. Fishery Board for Scotland, Scientific Investiga tions, 1912, No. II (December, 1913).
} 